\title{
MINERAL CARBONATION AS A POTENTIAL CARBON DIOXIDE STORAGE OPTION FOR THE REGION OF WESTERN MACEDONIA, GREECE
}

\author{
Koukouzas N. ${ }^{1}$, Ziock H. ${ }^{2}$, Ziogou F. ${ }^{1}$, and Typou I. $^{1}$ \\ ${ }^{1}$ Centre for Research \& Technology Hellas / Institute for Solid Fuel Technology \& Applications, \\ Ptolemais,Greece,koukouzas@techp.demokritos.gr,ziock@lanl.gov,ziogou@certh.gr, \\ itypou@lignite.gr \\ ${ }^{2}$ Los Alamos National Laboratory, Los Alamos, New Mexico
}

\begin{abstract}
The long-term storage of the greenhouse gas $\mathrm{CO}_{2}$ generated by fossil fuel-fired power plants in the form of stable mineral carbonates appears to be a promising option for reducing global $\mathrm{CO}_{2}$ emissions. In the case of mineral carbonation captured gaseous $\mathrm{CO}_{2}$ is chemically stored in an exothermic reaction by the carbonation of magnesium or calcium silicate minerals, forming environmentally benign and thermodynamically stable products. The purpose of this paper is to give an overview of the carbon dioxide storage by mineral carbonation and to examine the feasibility of this sequestration option in the region of Western Macedonia. The main candidate minerals for carbonation and their sequestration capacity are presented. Furthermore, the most promising mineral carbonation process routes as well as the thermodynamics and kinetics of carbonation reaction are addressed, based on a review on the published literature. In Greece abundant magnesium-rich ultramafic rocks exist that probably could support the national $\mathrm{CO}_{2}$ emissions abatement policy. The attractiveness stems from the favourable geographical relationship between large stationary $\mathrm{CO}_{2}$ emission sources and potential magnesium silicate deposits. Thus, a roughly description of the olivine deposits and their quality in the region of Western Macedonia will be provided.

Keywords: chemical fixation, reaction kinetics, olivine, Vourinos ophiolites.
\end{abstract}

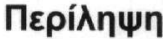

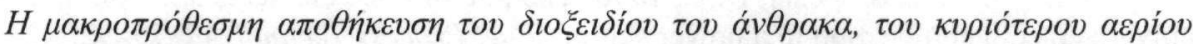

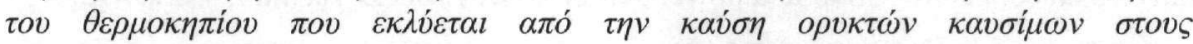

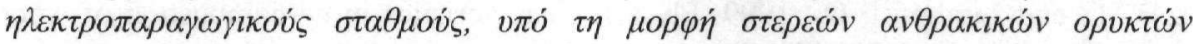

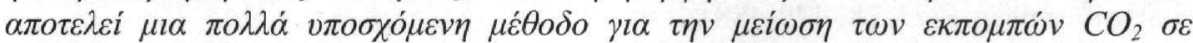

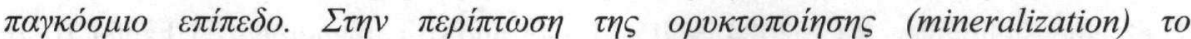

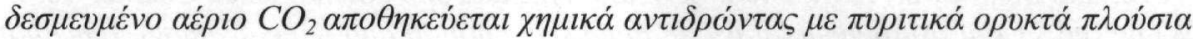

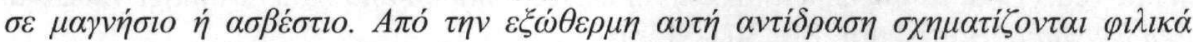

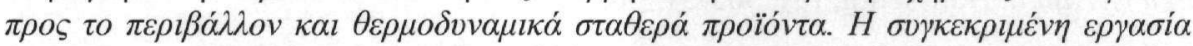

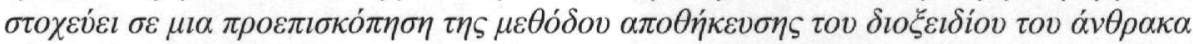

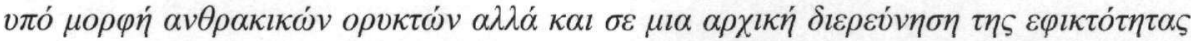

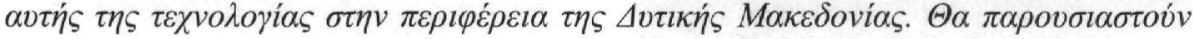




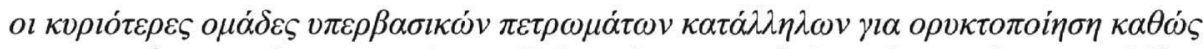

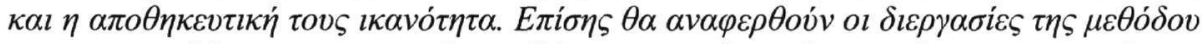

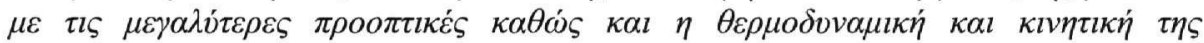

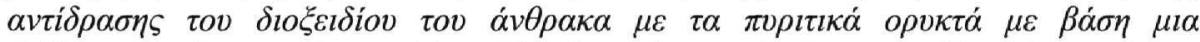

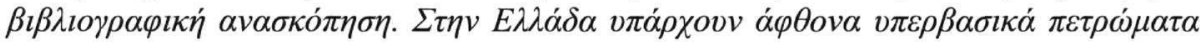

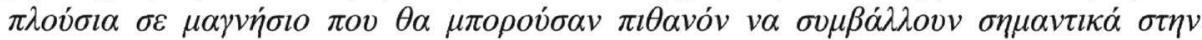

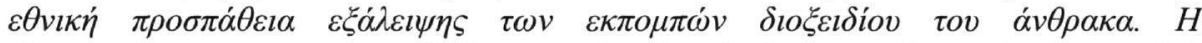

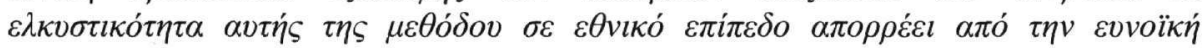

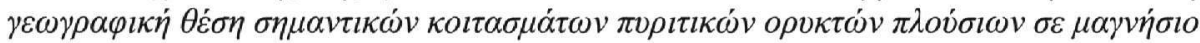

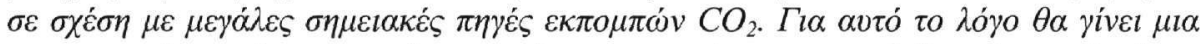

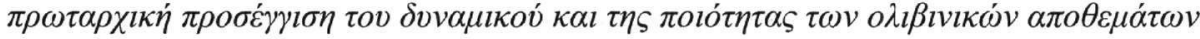

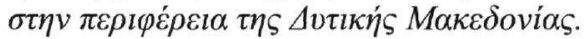

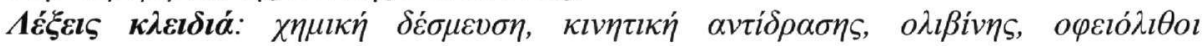
Boópivov.

\section{Introduction}

Fossil fuel combustion produces $\mathrm{CO}_{2}$, the main anthropogenic greenhouse gas, which when released into the atmosphere is responsible for enhancing the greenhouse effect leading to global warming. Fossil fuels are the main energy source and will continue to dominate global energy use. By 2030 it is projected that more than $80 \%$ of the world primary energy will be met by fossil fuels. The increased global demand for energy will in turn result in $\mathrm{CO}_{2}$ emissions increasing by about $62 \%$ (A Strategy for Developing Carbon Abatement Technologies for Fossil Fuel Use, Carbon Abatement Technologies Programme, Department of Trade and Industry (DTI), Department for Environment Food and Rural Affairs (DEFRA), June 2005, UK). In order to reduce the $\mathrm{CO}_{2}$ emissions from fossil fuel-fired power plants effective mitigation actions should be undertaken including higher efficiency conversion processes, fuel switching to low carbon or carbon-free energy sources and $\mathrm{CO}_{2}$ capture and storage methods (CCS). CCS technologies offer a great potential in reducing the $\mathrm{CO}_{2}$ emission (up to $85 \%$ ) from fossil fuel power plants (A Strategy for Developing Carbon Abatement Technologies for Fossil Fuel Use, Carbon Abatement Technologies Programme, June 2005, UK). The paper focuses only on carbon dioxide sequestration not capture, since different capture processes could be integrated. Potential technical storage methods are: geological storage (in underground permeable and porous rock formations), ocean storage (direct release into the ocean water column or onto the deep seafloor) and industrial fixation of $\mathrm{CO}_{2}$ into mineral carbonates (IPCC 2005).

Table 1 - Main Power Plants in Western Macedonia Region and $\mathrm{CO}_{2}$ emissions in 2005

\begin{tabular}{|c|c|c|}
\hline Power Plant & Installed capacity & $\begin{array}{c}\text { Emissions } \\
\text { (kt CO } \mathbf{2} / \mathbf{y r})\end{array}$ \\
\hline PPC S.A., TPS Ag. Dimitriou & $1595 \mathrm{MW}$ & 13,629 \\
\hline PPC S.A., TPS Kardias & $1250 \mathrm{MW}$ & 9,815 \\
\hline PPC S.A., TPS Ptolemaidas & $620 \mathrm{MW}$ & 3,488 \\
\hline PPC S.A., TPS Amyndaiou & $600 \mathrm{MW}$ & 5,124 \\
\hline PPC S.A., TPS Florinas & $330 \mathrm{MW}$ & 1,956 \\
\hline PPC S.A., TPS Liptol & $43 \mathrm{MW}$ & 358 \\
\hline Total & & 34,371 \\
\hline
\end{tabular}

Mineral carbon dioxide sequestration has three positive attributes compared to the rest storage options. First the carbonation reaction is exothermic and can theoretically produce energy as the 
formed mineral carbonates represent a lower energy state than $\mathrm{CO}_{2}$. Secondly, the sequestration capacity is large since the magnesium and calcium silicate deposits are available worldwide in quantities greater than the known fossil fuel reserves. Finally, the products of mineral carbonation occur naturally as stable solids because they are thermodynamically favoured. Their formation is due to natural $\mathrm{CO}_{2}$-rich fluids percolating through mineral deposits. Therefore, the storage of carbon dioxide is permanent and safe, eliminating the need to monitor the storage sites (Goff and Lackner 1998, Lackner et al. 1995).

Greece, as the second largest producer of lignite within the European Union, generates almost $93 \%$ of its electrical power requirements from fossil fuels with lignite accounting for about $64 \%$ of the total. There are two lignite centres, Ptolemais-Amynteo (LCPA) in the region of Western Macedonia and Megalopolis (LCM) in the southern region of Peloponnese. The proven lignite reserves of LCPA are 4.3 billion tons, corresponding to the $2 / 3$ of the total lignite deposits of Greece, with an annual production reaching 50 million tons (Koukouzas 1998). The largest Public Power Corporation's lignite-fired power plants in LCPA, representing $70 \%$ of the total electricity production are located in the region of Western Macedonia. As a result, $80 \%$ of the total annual $\mathrm{CO}_{2}$ emissions from the Greek lignite-fired electricity generation sector $\left(43,041 \mathrm{kt} / \mathrm{yr} \mathrm{CO}_{2}\right)$ derive from this region, as illustrated in Table 1 (Psomas 2006).

The disposal of carbon dioxide via the creation of magnesium or calcium carbonate solids as a sequestration option to mitigate climate change could enable lignite, Greece's only indigenous energy carrier, to stay competitive assuring the national energy security, the economic development as well as the environmental protection.

\section{Selection of minerals for the chemical fixation of carbon dioxide}

Calcium and magnesium oxides are generally selected for mineral $\mathrm{CO}_{2}$ sequestration purposes and are bound as a chemical combination with other oxides in the form of a silicate matrix. These silicate minerals are capable of being carbonated because the stronger carbonic acid is exchanged with the weaker silicic acid $\left(\mathrm{H}_{4} \mathrm{SiO}_{4}\right)$ (Huijgen and Comans 2003). These oxides are found in large quantities in ultramafic igneous rocks within large ophiolite complexes, exceeding the amount required for binding the carbon dioxide generated by fossil fuels combustion (Lackner et al. 1997). Although carbonation of calcium oxide is easier, the use of magnesium-based minerals (dunites, peridotites, and serpentinites) is favoured because they are available worldwide in large amounts and in relatively high purity (Huijgen and Comans 2003). The amount of oxide required to bind carbon dioxide from burning one ton of carbon, additionally, favours magnesium oxide at 3.3 tons compared to 4.7 tons of calcium oxide (Lackner et al. 1995). The composition of $\mathrm{Mg}$-bearing rocks and their specific $\mathrm{CO}_{2}$ sequestration capacity are listed in table 2. (Lackner et al. 1995, Huijgen and Comans 2003).

Table 2 - Composition of peridotites, serpentinites and their carbon dioxide sequestration capacity. $\mathbf{R}_{c}=$ mass ratio of rock needed for $\mathrm{CO}_{2}$ fixation to carbon burned. $\mathbf{R}_{\mathrm{CO}_{2}}=$ corresponding mass ratio of rock to $\mathrm{CO}_{2}$

\begin{tabular}{|c|c|c|c|c|}
\hline Rock & $\begin{array}{c}\text { MgO } \\
\text { [wt \%] }\end{array}$ & $\begin{array}{c}\mathrm{CaO} \\
{[\mathrm{wt} \%]}\end{array}$ & $\begin{array}{c}\mathbf{R}_{\mathrm{C}} \\
{[\mathbf{k g} / \mathbf{k g}]}\end{array}$ & $\mathrm{R}_{\mathrm{CO} 2}[\mathrm{~kg} / \mathrm{kg}]$ \\
\hline \multicolumn{5}{|l|}{ Peridotites } \\
\hline Dunite & 49.5 & 0.3 & 6.8 & 1.8 \\
\hline Harzburgite & 45.4 & 0.7 & 7.3 & 2.0 \\
\hline Lherzolite & 28.1 & 7.3 & 10.1 & 2.7 \\
\hline Serpentinite & $\sim 40$ & 0 & $\sim 8.4$ & $\sim 2.3$ \\
\hline
\end{tabular}




\section{Thermodynamics and kinetics of carbonation reaction}

The carbonation reactions of pure magnesium and calcium oxides are quite exothermic. The heat released can be compared to that one from the coal combustion (394 kJ/mol) (Lackner et al. 1997):

$$
\begin{gathered}
\mathrm{CaO}(\mathrm{s})+\mathrm{CO}_{2}(\mathrm{~g}) \rightarrow \mathrm{CaCO}_{3}(\mathrm{~s})+179 \mathrm{~kJ} / \mathrm{mol} \\
\mathrm{MgO}(\mathrm{s})+\mathrm{CO}_{2}(\mathrm{~g}) \rightarrow \mathrm{MgCO}_{3}(\mathrm{~s})+118 \mathrm{~kJ} / \mathrm{mol}
\end{gathered}
$$

Respectively, the carbonation reactions of calcium and magnesium oxides occurring as silicate minerals are still exothermic though to a lesser extent (Lackner et al. 1997):

$$
\begin{gathered}
\mathrm{Mg}_{3} \mathrm{Si}_{2} \mathrm{O}_{5}(\mathrm{OH})_{4} \text { (serpentine) }+3 \mathrm{CO}_{2} \rightarrow 3 \mathrm{MgCO}_{3}+2 \mathrm{SiO}_{2}+2 \mathrm{H}_{2} \mathrm{O}+64 \mathrm{~kJ} / \mathrm{mol}^{-1} \mathrm{CO}_{2} \\
\mathrm{Mg}_{2} \mathrm{SiO}_{4} \text { (fosterite) }+2 \mathrm{CO}_{2} \rightarrow 2 \mathrm{MgCO}_{3}+\mathrm{SiO}_{2}+90 \mathrm{~kJ} / \mathrm{mol}^{-1} \mathrm{CO}_{2}
\end{gathered}
$$

Actually, the carbonation reaction proceeds very slowly at room temperature and pressure. At ambient temperatures and 1 bar of $\mathrm{CO}_{2}$ pressure, the Gibbs free energy of the reaction favours the formation of carbonates (below $200{ }^{\circ} \mathrm{C}$ ). Although the temperature increase would overcome any activation energy barrier and improve the reaction kinetics, the chemical equilibrium favours gaseous $\mathrm{CO}_{2}$ over the carbonates at high temperatures due to entropy effects (Huijgen and Comans 2003). At 1 bar of $\mathrm{CO}_{2}$ pressure, the temperature limit is $900{ }^{\circ} \mathrm{C}$ for calcium carbonate and $410{ }^{\circ} \mathrm{C}$ for magnesium carbonate (Lackner et al. 1997).

\section{Mineral Carbonation Process Routes}

Two approaches for the carbonation of calcium and magnesium oxides can be distinguished:

- Direct carbonation, where the mineral is carbonated in one step either in a direct dry gassolid reaction or in an aqueous solution.

- Indirect carbonation, in which the reactive component is first extracted from the mineral structure by using various agents and then carbonated in a separate step at elevated pressure and temperature.

\subsection{Mineral pre-treatment options}

Many of the mineral carbonation processes include a pre-treatment option such as size reduction (crushing, grinding and milling), magnetic separation extraction of magnetite $\left(\mathrm{Fe}_{3} \mathrm{O}_{4}\right)$ and thermal treatment in order to accelerate the slow carbonation reaction kinetics. This is achieved by activating the reactive surface which in turn will speed up the metal oxide extraction from the mineral feedstock. However, the improved carbonation reactivity achieved by these pre-treatment activations is counteracted by the high energy requirements.

\subsection{Direct gas-solid carbonation at high temperatures}

The direct reaction of gaseous $\mathrm{CO}_{2}$ with $\mathrm{Mg}$-bearing silicate minerals (olivine or serpentine) in the solid state at suitable temperature and pressure levels is the simplest process. Moreover, the heat is released at elevated temperatures with minimum dilution. Since this process takes place too slowly at room temperatures, higher temperatures are required. However, if the temperature exceeds the calcination point, the chemical equilibrium shifts and the carbonation will not occur. Carbonation at atmospheric pressure and various temperatures $\left(140\right.$ to $300{ }^{\circ} \mathrm{C}$ ) was insignificant even when the experiments lasted for days (Lackner et al. 1995). Therefore, the direct carbonation requires high $\mathrm{CO}_{2}$ pressures or pre-treatment activation in order to obtain adequate reaction rates. However, as currently understood, this method does not appear to have a potential to become an industrially viable process. On the other hand, the carbonation rate of $\mathrm{Mg}(\mathrm{OH})_{2}$ appears to have a practical interest and proceeds in two steps occurring simultaneously (Huijgen and Comans 2003).

$$
\begin{gathered}
\mathrm{Mg}(\mathrm{OH})_{2} \rightarrow \mathrm{MgO}+\mathrm{H}_{2} \mathrm{O} \text { (dehydroxylation) } \\
\mathrm{MgO}+\mathrm{CO}_{2} \rightarrow \mathrm{MgCO}_{3} \text { (carbonation) }
\end{gathered}
$$


The optimum temperature reported is $375^{\circ} \mathrm{C}$ (Huijgen and Comans 2003). During the dehydroxylation of the hydroxide, fractures are formed into the crystal structure providing a greater reactive surface and thus a higher reactivity of $\mathrm{Mg}(\mathrm{OH})_{2}$ compared to $\mathrm{MgO}$ (Lackner et al. 1997). The steam may also play a catalytic role.

\subsection{Aqueous direct carbonation route}

From natural serpentinization reaction of ultramafic minerals, it is known that the presence of water induces reactions. Based on this principle, aqueous direct carbonation route refers to a process which utilizes a slurry of fine particle sized mineral in water with solid concentration from 15 to $30 \%$, at elevated temperature (below $200{ }^{\circ} \mathrm{C}$ ) and high $\mathrm{CO}_{2}$ pressure. A process flow diagram of the aqueous process route is illustrated in Figure 1 (Goldberg 2001). Optimal conversions reported are $91 \%$ in 6 hours for olivine at $185^{\circ} \mathrm{C}$ and $34 \%$ in 6 hours for serpentine at $155^{\circ} \mathrm{C}\left(80 \%\right.$ of minerals ground to $<37 \mu \mathrm{m}$ and $\mathrm{P}_{\mathrm{CO} 2}$ of $\left.150 \mathrm{~atm}\right)$ (O'Connor et al. 2005).

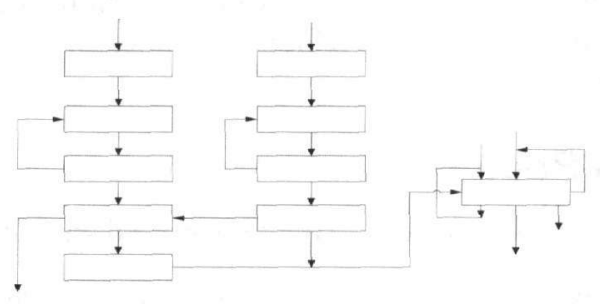

Figure 1 - Process flow diagram of the aqueous direct carbonation route

The aqueous mineral $\mathrm{CO}_{2}$ sequestration is conducted via three reactions that take place simultaneously in one reactor (O'Connor et al. 2005):

First, $\mathrm{CO}_{2}$ is dissolved in distilled water to form carbonic acid which dissociates to bicarbonate and $\mathrm{H}^{+}$:

$$
\mathrm{CO}_{2}+\mathrm{H}_{2} \mathrm{O} \rightarrow \mathrm{H}_{2} \mathrm{CO}_{3} \rightarrow \mathrm{H}^{+}+\mathrm{HCO}_{3}^{-}
$$

Then, mineral hydrolysis liberates $\mathrm{Mg}^{2+}$ cations from the olivine matrix with co-production of silica acid or free silica and water:

$$
\mathrm{Mg}_{2} \mathrm{SiO}_{4}+4 \mathrm{H}^{+} \rightarrow 2 \mathrm{Mg}^{2+}+\mathrm{H}_{4} \mathrm{SiO}_{4} \text { or } \mathrm{SiO}_{2}+2 \mathrm{H}_{2} \mathrm{O}
$$

Finally, the $\mathrm{Mg}^{2+}$ cations react with bicarbonate ions to form magnesite:

$$
\mathrm{Mg}^{2+}+\mathrm{HCO}_{3}^{-} \rightarrow \mathrm{MgCO}_{3}+\mathrm{H}^{+}
$$

In aqueous carbonation the rate-limiting step appears to be the dissolution rate of the minerals, although the formation of carbonic acid also plays an important limiting role. Since dissolution is surface-controlled, the formation of silica or carbonates layers on the dissolving mineral particles tends to hinder further carbonation (Huijgen and Comans 2003, IPCC 2001). The operating parameters such as mineral particle size, $\mathrm{CO}_{2}$ pressure and temperature determine the dissolution extent. The use of high $\mathrm{CO}_{2}$ pressure and the mineral pre-treatment (fine grinding, heat treatment of serpentine) are energy consuming. On the other side, the temperature raise improves the 
dissolution kinetics but the carbonate precipitation slows down due to reduced solubility of carbon dioxide and the change in the available free energy (O'Connor et al. 2005).

In order to further improve the reaction extent. a bicarbonate/salt mixture $\left(\mathrm{NaHCO}_{3} / \mathrm{NaCl}\right)$ in water with concentrations $1 \mathrm{M} \mathrm{NaCl}$ and $0.5-0.64 \mathrm{M} \mathrm{NaHCO}_{3}$ can be used. The $\mathrm{NaHCO}_{3}$ addition increases the $\mathrm{HCO}_{3}{ }^{-}$concentration favouring the carbonate precipitation. An increase of $0.5-1.0 \mathrm{~g} / \mathrm{l}$ $\mathrm{CO}_{2}$ in distilled water to $20 \mathrm{~g} / 1 \mathrm{CO}_{2}$ in a $\mathrm{NaHCO}_{3} / \mathrm{NaCl}$-solution has been reported (Huijgen and Comans 2003). Conversion of nearly $80 \%$ was achieved for olivine in 30 minutes in test conditions of $155^{\circ} \mathrm{C}$ and $185 \mathrm{~atm} \mathrm{P}_{\mathrm{CO} 2}$. The solution is buffered at $\mathrm{pH} 7.7$ to 8.0 and the reaction sequence is modified to (O'Connor et al. 2005):

$$
\mathrm{Mg}_{2} \mathrm{SiO}_{4}+2 \mathrm{HCO}_{3}^{-} \rightarrow 2 \mathrm{MgCO}_{3}+\mathrm{SiO}_{2}+2 \mathrm{OH}^{-}
$$

The bicarbonate is almost immediately regenerated due to the reaction of the hydroxyl ion with gaseous carbon dioxide:

$$
\mathrm{OH}^{-}+\mathrm{CO}_{2} \rightarrow \mathrm{HCO}_{3}^{-}
$$

Thus, the addition of $\mathrm{NaCl}$ increases the ionic strength of the solution, lowering the magnesium activity. Furthermore, the $\mathrm{Mg}^{2+}$ cations solubility is enhanced by creating soluble complexes $\left(\mathrm{MgCl}_{2}, \mathrm{MgCl}_{3}{ }^{-}, \mathrm{MgCl}_{4}{ }^{2-}\right.$, etc.), (Huijgen and Comans 2003).

\subsection{Carbonation route by hydrochloric acid extraction}

Serpentine or forsterite dissolve in a solution containing about $20 \%$ hydrochloric acid forming hydrated magnesium chloride and silica gel (Fig. 2), (Lackner et al. 1997). Consequently, the magnesium content is extracted. Silica precipitates simultaneously with the iron oxide content of the feedstock ( 8 to $10 \%$ ), after raising the $\mathrm{pH}$ of the solution by neutralizing the solution with $\mathrm{MgCI}(\mathrm{OH})$, which is generated in another step of the process. For serpentine the process steps are (Lackner et al. 1997):

$$
\mathrm{Mg}_{3} \mathrm{Si}_{2} \mathrm{O}_{5}(\mathrm{OH})_{4}+6 \mathrm{HCl}+\mathrm{H}_{2} \mathrm{O} \rightarrow 3 \mathrm{MgCl}_{2} \cdot 6 \mathrm{H}_{2} \mathrm{O}+2 \mathrm{SiO}_{2}\left(\mathrm{~T}=100^{\circ} \mathrm{C}-110^{\circ} \mathrm{C}, \mathrm{P}=1 \text { bar }\right)
$$

Consecutively, the $\mathrm{MgCl}_{2} \cdot 6 \mathrm{H}_{2} \mathrm{O}$ is hydrolyzed at 200 to $250^{\circ} \mathrm{C}$. Initially, the associated water is removed, resulting in $\mathrm{MgCl}_{2} \cdot \mathrm{H}_{2} \mathrm{O}$ and finally, the hydrochloric acid is recovered by further heating. The acid recovery is the only endothermic stage of the process. The temperature increase during this step enables the hydrogen chloride and the water to be removed as vapour:

$$
\mathrm{MgCl}_{2} \cdot 6 \mathrm{H}_{2} \mathrm{O} \rightarrow \mathrm{Mg}(\mathrm{OH}) \mathrm{Cl}+\mathrm{HCl}+5 \mathrm{H}_{2} \mathrm{O}
$$

Then, $\mathrm{Mg}(\mathrm{OH}) \mathrm{Cl}$ disassociates in an aqueous solution into magnesium hydroxide and magnesium chloride, according to the following reaction:

$$
2 \mathrm{Mg}(\mathrm{OH}) \mathrm{Cl} \rightarrow \mathrm{Mg}(\mathrm{OH})_{2}+\mathrm{MgCl}_{2}
$$

Figure 2 - Process flow diagram for $\mathrm{Mg}$ carbonation route by $\mathrm{HCl}$ extraction. The mass flows correspond to $\mathrm{CO}_{2}$ emissions of a $1 \mathrm{GW}$ power plant with $33 \%$ conversion efficiency 
Finally, the precipitated $\mathrm{Mg}(\mathrm{OH})_{2}$ is nearly completely carbonated in thirty minutes, at elevated temperatures $\left(500-600^{\circ} \mathrm{C}\right.$ ) and pressures of 50 bar enabling the better use of the heat released by the exothermic reaction:

$$
\mathrm{Mg}(\mathrm{OH})_{2}+\mathrm{CO}_{2} \rightarrow \mathrm{MgCO}_{3}+\mathrm{H}_{2} \mathrm{O}
$$

The hydrochloric acid should be effectively regenerated after dissolving the magnesium component of the rock. All chlorides are passed on to the acid recovery step in the form of magnesium chloride and thus, great losses of hydrochloric acid could be caused by the formation of alkali metal chlorides. Fortunately, typical serpentine or peridotite are essentially free of alkali metals (<0.5 wt-\%) (Lackner et al. 1997).

\section{Comparison of process routes}

Besides the straightforward design, the main advantage of the direct dry routes is that the heat released during the carbonation reaction is available at high temperatures aNd thus, can be applied in other parts of the process. Nonetheless, the reaction rate is too low at thermodynamically allowed temperatures and the $\mathrm{CO}_{2}$ pressure needed is higher compared to indirect process routes (Huijgen and Comans 2003).

Despite the fact that aqueous mineral carbonation has achieved acceptable conversion rates, the current need for energy-intensive heat treatment leads to high process costs. Moreover, due to the high degree of dilution into a large amount of water and the lower reaction temperature, the heat of the reaction is not practically useful. Another possible disadvantage of the aqueous route with modified solution chemistry is the need for additional chemicals in the case of their incomplete recovery (IPCC 2001).

In contrast, the hydrochloric acid extraction route requires a net energy input for the regeneration of the acid due to the fact that water evaporation and condensation steps occur at temperatures higher than the exothermic steps (Lackner et al. 1997). Another preoccupation appears to be the costs associated with the use of hydrochloric acid owing to its highly corrosive nature and the excessive make-up needs (Haywood et al. 2001).

\section{Magnesium silicates in Western Macedonia}

There are three ophiolitic belts of late Jurassic age occurring in West Macedonia. The eastern is a series of tectonic fragments, serpentinised ultramafic mantle rocks, at the borders of West Macedonia and Veria city (mountain Vermion). The major ophiolitic belts are those exposed at Mount Vourinos and the mountain chain of Pindos.

The Pindos ophiolite complex of NW Greece is located in the Subpelagonian Zone and covers an area of about $2000 \mathrm{Km}^{2}$. Peridotites extend over at least $600 \mathrm{Km}^{2}$ (Dabitzias and Rassios 2000). This complex is composed of several tectonic units. The uppermost tectonic unit is the Pindos Ophiolite Group. The Ophiolite Group is divided into three sub-units (from top to bottom): i) the Dramala Complex consists of locally serpentinized, depleted mantle harzburgite, dunite, pyroxenite, and assorted ultramafic cumulates that directly overlie ii) the Loumnitsa Unit which is the metamorphic sole of the ophiolite; iii) the Aspropotamos Complex is an ophiolitic horizon containing dismembered ultramafic cumulates, intrusives, and mafic extrusives.

The Vourinos Ophiolite Complex was emplaced on the Western margin of the Pelagonian zone during Late Jurassic-Early Cretaceous times (Mountrakis 1983, Mountrakis 1986, Smith 1979). The Vourinos Ophiolite Complex (Fig. 3, Margaras and Vacondios 1996) with minimal stratigraphic disruption, is exposed over an area of about $30 \mathrm{~km}$ by $15 \mathrm{~km}$ at an estimated thickness of $10 \mathrm{~km}, 30 \mathrm{~km} \mathrm{SW}$ of the city of Kozani (Brunn et al. 2004, Ross et al. 1980). 


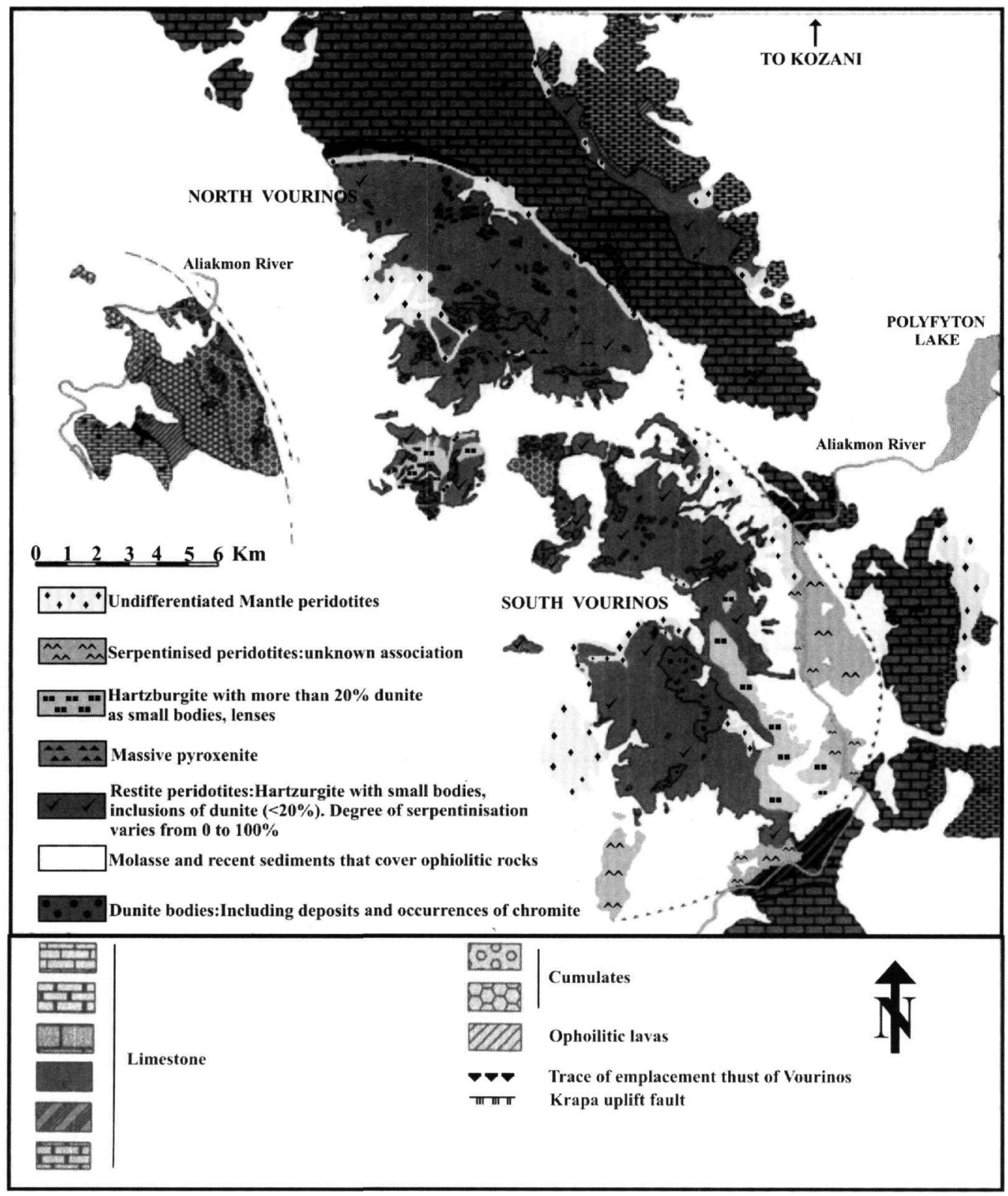

Figure 3 - Simplified Geological map with Magnesium silicate deposits of Vourinos Ophiolite Complex

Hartzburgites with interlaminated dunites in equal proportions comprise about $85 \%$ of Vourinos Complex (Ross et al. 1980). In addition, mafic and ultramafic cumulates, diorites, sheeted dikes, pillow lavas, amphibolites and metamorphic sediments parts of the sole are present (Moores 1969, Rassios et al. 1983) while a layer of a Late Jurassic calpionellid limestones lies on the ophiolites (Mavrides et al. 1977). Within the northern block of Vourinos Ophiolite Complex, the thickness of the individual unserpentinized ultramafic rocks layers varies from a few centimetres to several meters while layers of dunite vary in thickness from $10 \mathrm{~m}$ to $200 \mathrm{~m}$ with higher degree of serpentinization within the southern block, (Ross et al. 1980). However, the largest dunite deposits of Vourinos Complex are those of Xerolivado whose lengths are greater than $5 \mathrm{~km}$ (Dabitzias and Rassios 2000). In addition, fresh slightly serpentinized dunites and harzburgites occur in a belt 
$20 \mathrm{~km}$ long and 0.5 to $1 \mathrm{~km}$ thickness, between the basal thrust sole of the ophiolite and the zone of chromites (Dabitzias and Rassios 2000).

\section{Investigation of mineral carbonation's potential in Western Macedonia}

According to chemical analyses carried out by the Institute Of Geology \& Mineral Exploration, olivine, chromite, and orthopyroxene (average content $8 \%$ ) are the main mineralogical phases of these deposits. The range of the major elements' concentration is listed in Table 3. (Institute of Geology \& Mineral Exploration, Greece). These Mg-rich silicate minerals with an average MgO content $\sim 45$ wt-percent and little pyroxene represent desirable ores for the chemical fixation of carbon dioxide (Lackner et al. 1997).

Table 3 - The range of the chemical composition (in wt- \%) of ultramafic rocks from Vourinos Complex

\begin{tabular}{|c|c|}
\hline $\mathrm{SiO}_{2}$ & $40.64-42.78$ \\
\hline $\mathrm{Al}_{2} \mathrm{O}_{3}$ & $0.38-0.57$ \\
\hline $\mathrm{Fe}_{2} \mathrm{O}_{3}$ & $8.00-8.72$ \\
\hline $\mathrm{CaO}$ & $0.28-0.98$ \\
\hline $\mathrm{MgO}$ & $43.52-46.52$ \\
\hline $\mathrm{K}_{2} \mathrm{O}$ & 0.01 \\
\hline $\mathrm{Na}_{2} \mathrm{O}$ & 0.03 \\
\hline $\mathrm{MnO}$ & $0.10-0.13$ \\
\hline $\mathrm{TiO}_{2}$ & 0.01 \\
\hline $\mathrm{Cr}_{2} \mathrm{O}_{3}$ & $0.34-1.59$ \\
\hline $\mathrm{NiO} \mathrm{OI}$ & $0.31-0.34$ \\
\hline $\mathrm{LO}$ & $1.50-3.37$ \\
\hline
\end{tabular}

TPS AG. DIMITRIOU and TPS KARDIAS, the largest power plants in the region, are located at the favourable distance of $50 \mathrm{~km}$ from the potential mineral resources of the Vourinos Complex (Fig. 3). Due to their proximity, an integrated concept of mineral carbonation and carbon dioxide capture should be considered. Based on the average $\mathrm{MgO}$ content ( $45 \%$ by wt) in the regional silicate ores (Table 3), it has been estimated that for the sequestration of $1 \mathrm{t} \mathrm{CO}_{2}, 2.82 \mathrm{t}$ of ultramafic ore should be mined and processed, assuming $90 \%$ ore recovery and $80 \%$ conversion in the carbonation reaction. In addition, about $99 \mathrm{Mt} / \mathrm{yr}$ of ore will be needed to fix all the carbon dioxide output of the regional power plants, requiring a deposit with an estimated volume of at least $0.03 \mathrm{~km}^{3}$ (average peridotites density $\sim 3.3 \mathrm{~g} / \mathrm{cm}^{3}$, Goff and Lackner 1998). Considering only the serpentinized dunites and harzburgites body at Xerolivado $(20 \mathrm{~km}$ long, $0.5 \mathrm{~km}$ thick and assumed $0.5 \mathrm{~km}$ wide), it could be concluded that this deposit alone could dispose of all the carbon dioxide emissions of the region for over one hundred years. Nonetheless, these values represent only a rough estimate. For this reason, a more detailed evaluation of the available silicate resources should be made so as to assess with higher certainty the sequestration reactivity for the regional mineral deposits. Furthermore, the disposal of carbonate waste, due to large chrome mining activities conducted in the past, could probably fill the large open pits left accelerating the landscape reclamation in Vourinos Complex.

Intensive research activities related to the further development of the carbonation process are currently carried out by the DOE-funded Mineral Carbonation Research Cluster which consists of Los Alamos National Laboratory, Albany Research Center, Arizona State University, National Energy Research Laboratory, and Science Applications International Corporation. It is worth mentioning that a bilateral collaboration of CERTH/ISFTA (Centre for Research \& Technology Hellas / Institute for Solid Fuel Technology \& Applications) in Greece and LANL (Los Alamos 
National Laboratory) has recently started in the field of mineral carbonation. The aim of this project is to provide some basic information concerning the implementation's feasibility of this concept to fossil fuel-fired power plants located in the region of Western Macedonia.

Within this project the composition and quality of various samples from regional silicate deposits will be characterised through a series of mineralogy and chemical analyses. In addition, laboratory carbonation tests will be carried out in order to get some basic data about the carbonation reactivity of these samples in a range of different temperatures and pressures.

In the case that the results of the experiments show promise further studies will then be focused on:

- Assessing the actual scale of the minerals required for an industrial-scale operation in order to identify the location of the mineral carbonation plant at the mineral site or at the fossil fuel-fired power plant.

- Evaluating the economic feasibility of $\mathrm{CO} 2$ sequestration by mineral carbonation in the Region of Western Macedonia taking into account the energy requirements as well as the production of value-added by-products, such as silicon, chrome bouNd as chromite etc. that may offset the carbonation costs.

- Adressing the potential environmental issues related to mineral carbonation such as the large-scale open pit mining impact, the extra emissions due to the increased energy consumption, and the disposal of tailings.

\section{Conclusions}

On the whole, sequestration of carbon dioxide in mineral form appears to be an attractive option due to many fundamental advantages such as:

- Long term stability since the products of mineral carbonation occur naturally as stable solids due to natural $\mathrm{CO}_{2}$-rich fluids percolating through mineral deposits. In addition the formed are thermodynamically stable providing a permanent and safe storage of carbon dioxide and thus, eliminating the monitoring requirements.

- Vast capacity of ultramafic rocks suitable to fix carbon dioxide far exceeding the known fossil fuel reserves.

- Potential to be economically viable owing to the exothermic nature of the carbonation reaction.

Currently, the main challenge is the development of faster carbonation reaction rates in a costeffective and energetically acceptable way so as to maximize the competitive advantages of this concept.

At national level, mineral carbonation merits further investigation as a promising technology for carbon dioxide abatement. At first glance, the sequestration potential of Western Macedonia appears considerable. The basic geology of Vourinos Complex is well-known and the distribution and volume of Mg-rich rocks is significant. In addition, the proximity of the mineral deposits to large $\mathrm{CO}_{2}$ sources is another positive attribute. However, a more detailed mapping and evaluation of the magnesium silicate mineral resources is recommended in line with the results generated by the laboratory tests in order to determine the scale of application for mineral carbonation.

\section{References}

Brunn, J.H., Argyriadis, I., and Braud, J., 2004. Magmatic emplacement of ophiolites in Northern Greece, Bulletin of the Geological Society of Greece, XXXVI, Proceedings of the 10th International Congress, Thessaloniki, April. 
Dabitzias, S., and Rassios, A., 2000. Hartzburgites/dunites for high quality olivine products in the Vourinos and Pindos Ophiolite Complexes, $1^{\text {st }}$ Conference of Economic Geology, Mineralogy \& Geochemistry, Kozani, 330-340.

Goff, F., and Lackner, K. S., 1998. Carbon Dioxide Sequestering Using Ultramafic Rocks, Environmental Geoscience, 5(3), 89-101.

Goldberg, P., 2001. CO2 Mineral Sequestration Studies in US: Introduction, Issues and Plans, National Energy Technology Laboratory Workshop on $\mathrm{CO}_{2}$ Sequestration with Minerals.

Haywood, H. M., Eyre, J. M., and Scholes, H., 2001. Carbon dioxide sequestration as stable carbonate minerals-environmental barriers, Environ. Geol., 41, 11-16.

Huijgen, W.J.J., and Comans, R.N.J., 2003. Carbon dioxide sequestration by mineral carbonation, literature review, Energy research Centre of the Netherlands, ECN-C-03-016, Petten, The Netherlands.

IPCC, 2001. Special Report on Carbon Dioxide Capture and Storage, Mineral carbonation and industrial uses of carbon dioxide (Chapter 7).

IPCC/TEAP, 2005. Special Report, Carbon Dioxide Capture and Storage. ISBN 92-9169-119-4.

Koukouzas, N., 1998. Distribution of lignite deposits based on the age, quality and their deposits, Mineral Wealth, 106/1998.

Lackner, K.S., Wendt, C. H., Butt, D. P.; Joyce, E. L., and Sharp, D. H., 1995. Carbon dioxide disposal in carbonate minerals, Energy, 20, 1153-1170.

Lackner, K. S., Butt, D. P., Wendt, C. H., Goff, F., and Guthrie, G., 1997. Carbon Dioxide Disposal in Mineral Form: Keeping Coal Competitive, Tech. Report No. LA-UR-97-2094 (Los Alamos National Laboratory).

Margaras, S., and Vacondios, I., in collaboration with Grivas, E., Konstantopoulou, G., and Rassios, A., 1996. The Vourinos Ophiolite Complex, Northern Greece.

Mavrides, A., Skourtsis-Coroneou, V., and Tsalia-Monopolis, S., 1977. Contribution to the geology of the Subpelagonian zone (Vourinos area, West Macedonia). In VI Coll. Aegean region, $I$, 175-195pp.

Moores, E., 1969. Petrology and structure of the Vourinos ophiolitic complex of Northern Greece. Geol. Soc. Amer. Spec., 118, 74.

Mountrakis, D., 1983. Structural geology of the North Pelagonian zone s.l. and geotectonic evolution of the internal Hellenides. Unpubl. "Habilitation", Univ. Thessaloniki, Greece, 283 pp.

Mountrakis, D., 1986. The Pelagonian zone in Greece: a polyphase deformed fragment of the Cimmerian continent and its role in the geotectonic evolution of East Mediterranean. $J$. of Geology, 94, 335-347.

O’Connor, W.K., Dahlin, D.C., Rush, G.E., Gedermann, S.J., Penner, L.R., and Nilsen, D.N., 2005. Aqueous mineral carbonation. Final Report, DOE/ARC-TR-04-002.

Psomas, S., 2006. The end of lignite and the transition towards a new energy period. $w w w$. greenpeace.com, October 2006, Athens, Greece.

Rassios, A., Beccaluva, L., Bortolotti, V., Mavrides, A. and Moores, E. M., 1983. Vourinos ophiolite complex: field guidebook for workshop on Vourinos Guevgueli ophiolites, IGCP 197, 34pp. 
Ross, J.V., Mercier, J-CC., Lallement, H.G. Ave, Carter, N.L., and Zimmerman, J., 1980. The Vourinos ophiolite complex, Greece: The tectonic suite, Tectonophysics, 70, 63-83.

Smith, A.G., 1979. Orthris, Pindos and Vourinos ophiolites and the Pelagonian zone. In VI Coll. Aegean region, III, 1369-1374. 